\title{
THE EFFECT OF USING QUAIL LITTER BIOCHAR ON SOYBEAN (Glycine $\max$ [L.] Merr.) PRODUCTION
}

\author{
Tawadchai Suppadit ${ }^{1 *}$, Nittaya Phumkokrak ${ }^{2}$, and Pakkapong Poungsuk ${ }^{3}$
}

Biochars can be used as soil amendments for improving soil properties and crop yield. The objective of this research was to study the plant growth, yield, yield components, and seed quality, including nutrients and heavy metals $(\mathrm{Pb}, \mathrm{Cd}$, and $\mathrm{Hg})$, in the soybean plant (Glycine max [L.] Merr.) and soil. The experiment was conducted from September 2010 to January 2011 in a greenhouse located in the Dan Khun Thot District, Nakhon Ratchasima Province, Thailand. The research comprised six treatments with four replicates in a completely randomized design. Quail litter biochar (QLB) at rates of 0, 24.6, 49.2, 73.8, 98.4 and 123 g per pot mixture were provided to soybean cv. Chiang Mai 60. The results showed that QLB could be used as a soil fertility improvement and amendment for soybean production with an optimum rate of $98.4 \mathrm{~g}$ per pot mixture, which gave the best performance in terms of the number of nodes, height, DM accumulation, total yield, and seed quality. After the experiment, the nutrient contents in the soil increased as the QLB content increased, but the heavy metal residues in the leaves and seeds did not change. However, QLB at levels higher than $98.4 \mathrm{~g}$ per pot mixture is not advisable because $\mathrm{QLB}$ is alkaline in nature, which may affect soil $\mathrm{pH}$.

Key words: Crop yield, element, nutrient uptake, pyrolysis, soil fertility.

$\mathrm{T}$ he Japanese quail (Coturnix japonica) is an excellent bird for commercial domestication because of its rapid growth, high laying, fecundity and environmental resistance compared to chickens (Iwamoto et al., 2008). In Thailand, Japanese quail production has undergone steady growth all over the country during the past 20 $\mathrm{yr}$, and the production of quail egg and meat is expected to further increase in response to increasing domestic consumption and export (Suppadit, 2009). The total census of quail in 2009 was approximately 5.2 million (Department of Livestock Development, 2010), which resulted in an estimated annual production of 3600$3700 \mathrm{t}$ fresh quail litter (1000 birds produce $0.704 \mathrm{t}$ of litter in raising between starter and maturity stages) (Suppadit, 2009). Quail litter refers to the combination of accumulated manures, feathers, spilled feed, and bedding materials, which is composed of rice (Oryza sativa L.) hulls (Suppadit et al., 2009). The high organic matter and nutrient content of quail litter along with its positive effects on soil texture have encouraged its exploitation on agricultural soils (López-Mosquera et al., 2007; Bernhart

${ }^{1}$ Graduate School of Social and Environmental Development, National Institute of Development Administration, Bangkapi, Bangkok 10240, Thailand. *Corresponding author (stawadchai@yahoo.com).

${ }^{2}$ Duangkamol Farm, Hin Dard Sub-District, Dan Khun Thot District, Nakhon Ratchasima 30210, Thailand.

${ }^{3}$ King Mongkut's Institute of Technology Ladkrabang, Faculty of Industrial Education, Ladkrabang, Bangkok 10520, Thailand.

Received: 23 May 2011.

Accepted: 26 March 2012. and Fasina, 2008; Suppadit et al., 2008a) because quail litter not only improves soil fertility and aeration but also increases water holding capacity of soil (Gupta and Gardner, 2005; Suppadit et al., 2008b).

However, if there is no corrective treatment of quail litter, it produces a foul odor, thus affecting environmental health. Quail litter can also become a source of disease pathogens and produce poisonous gases from fermentation. When quail litter is washed away into a surface water source, it increases nutrients for water plants. If water plants grow in abundance, this will eventually reduce oxygen in the water and negatively affect aquatic animals (Suppadit, 2002). However, if quail litter is properly handled, such waste can be used as a fertilizer for crop production. Quail litter has a high nutritional value when used as an organic fertilizer because nutrients, such as $\mathrm{N}, \mathrm{P}$, and $\mathrm{K}$, will be recycled. These components in quail litter have traditionally been used as an amendment (Suppadit, 2005). However, the process of transforming quail litter into fertilizer is rather complicated. There are also problems with flies, dust, and odor. Promising approaches for reducing these problems or restrictions of fresh quail litter include pelleting, extrusion, and thermal processes (Suppadit, 2009).

Thermal processing of quail litter provides an additional option to manage this waste and to upgrade it to biogas, bio-oil, and biochar (Chan et al., 2008; Jaime and Salazar, 2010). Biochar is a product of thermal decomposition of biomass produced by the process called pyrolysis (heating in the absence of oxygen) (Chen et al., 
2010). Biochar is attracting international attention for the following two reasons: 1) biochars can be used as soil amendments for improving soil properties and crop yield; and 2) storing biochars in soils is regarded as a means for permanently sequestering $\mathrm{C}$ and a potential abatement option for anthropogenic C emissions (Glaser et al., 2002; Lehmann, 2007; Hossain et al., 2010; Uzoma et al., 2011). The latter can be attributed to the relative stable nature of biochar, and the long turnover time of biochar in soil is of particular relevance for climate change solutions (Lehmann et al., 2006; Kookana, 2010). The conversion of quail litter by pyrolysis to produce biochar has potential to increase conventional agricultural productivity (Suppadit, 2009). Meanwhile, the understanding of agricultural effects of biochar is limited (Hossain et al., 2010). Previous studies have examined the useful effects of biochar produced from poultry litter (Chan et al., 2008), wastewater sludge (Hossain et al., 2010), and cow manure (Uzoma et al., 2011) on the yield of agricultural crop and properties of soil, and these studies have found that biochars significantly improve the yield of crops and properties of soil. However, there is currently no available information regarding the use of quail litter biochar (QLB) and its effects on soil and plant nutrients. Thus, studying the influence of biochar derived from quail litter on crop productivity merits research.

The objectives of the current study were to investigate the effect of different mixing rates of QLB on soybean (Glycine max L.] Merr.) production in a greenhouse pot experiment in terms of growth, yield and seed quality and to investigate the impact of QLB on soil quality and bioavailability of heavy metals in soybean leaves and seeds.

\section{MATERIALS AND METHODS}

\section{Soils}

The soil used in this study was collected from the Dan Khun Thot soil group (Ustic Quartzipsamments, sandy, siliceous, coated, and isohyperthermic) and was classified as sandy soil containing $94.0 \%$ sand, $2.5 \%$ silt, and $3.5 \%$ clay (Land Development Department, 2011). The selected soil had the appropriate physical and chemical properties for agriculture to better determine the effect of treatment conditions using QLB on soybean growth and production. A composite sample was collected $10 \mathrm{~cm}$ below the topsoil layer, and the sample was sieved through a 6 mm sieve according to methods of Hossain et al. (2010) prior to analysis and potting. Table 1 shows the chemical characteristics, nutrients, and heavy metals in the sandy soil before the experiment.

\section{Quail litter biochar}

The biochar used in this study was produced from quail litters. Quail litters were randomly selected from farms located in the Singburi Province, Thailand. QLB was produced at a $500{ }^{\circ} \mathrm{C}$ pyrolysis temperature based on
Table 1. Chemical characteristics of soil and quail litter biochar (QLB) used in the pot experiment.

\begin{tabular}{lcc}
\hline Characteristics & Soil & QLB \\
\hline $\mathrm{EC}, \mathrm{dS} \mathrm{m}^{-1}$ & 0.100 & 2.20 \\
$\mathrm{pH}$ & 6.10 & 9.10 \\
Exchangeable cations & & \\
$\mathrm{CEC}, \mathrm{cmol} \mathrm{kg}^{-1}$ & 0.920 & 6.35 \\
$\mathrm{~K}, \mathrm{cmol} \mathrm{kg}^{-1}$ & 0.200 & 0.28 \\
$\mathrm{Ca}, \mathrm{cmol} \mathrm{kg}^{-1}$ & 0.430 & 2.34 \\
$\mathrm{Mg}, \mathrm{cmol} \mathrm{kg}^{-1}$ & 0.175 & 1.52 \\
$\mathrm{Elements}$ & & \\
$\mathrm{C}, \mathrm{mg} \mathrm{kg}^{-1}$ & 1260 & 32800 \\
$\mathrm{Total} \mathrm{N}, \mathrm{mg} \mathrm{kg}^{-1}$ & 194 & 1620 \\
$\mathrm{C} / \mathrm{N} \mathrm{ratio}$ & 6.49 & 20.2 \\
$\mathrm{P}, \mathrm{mg} \mathrm{kg}^{-1}$ & 586 & 9620 \\
$\mathrm{~K}, \mathrm{mg} \mathrm{kg}^{-1}$ & 704 & 6750 \\
$\mathrm{Ca}, \mathrm{mg} \mathrm{kg}^{-1}$ & 1022 & 10050 \\
$\mathrm{Mg}, \mathrm{mg} \mathrm{kg}^{-1}$ & 324 & 020 \\
$\mathrm{Fe}, \mathrm{mg} \mathrm{kg}^{-1}$ & 4.10 & 910 \\
$\mathrm{Zn}, \mathrm{mg} \mathrm{kg}^{-1}$ & 0.156 & 182 \\
$\mathrm{Cu}, \mathrm{mg} \mathrm{kg}^{-1}$ & 0.860 & 143 \\
$\mathrm{Mn}, \mathrm{mg} \mathrm{kg}^{-1}$ & 13.6 & 342 \\
$\mathrm{Heavy} \mathrm{metals}$ & & \\
$\mathrm{Pb}, \mathrm{mg} \mathrm{kg}^{-1}$ & 2.10 & 44.5 \\
$\mathrm{Cd}, \mathrm{mg} \mathrm{kg}^{-1}$ & 2.40 & 14.8 \\
$\mathrm{Hg}, \mathrm{mg} \mathrm{kg}^{-1}$ & 1.32 & 1.8 \\
\hline $\mathrm{CEC} \mathrm{Can}$. & & \\
\hline
\end{tabular}

CEC: Cation exchange capacity.

the recommendation of Lehmann (2007). The quail litter was packed into a ceramic container, which was covered with a lid, and combusted in a muffle furnace (K-SF05, Humanlab, K\&K Scientific Supplier, Seoul, South Korea) at $500{ }^{\circ} \mathrm{C}$ for $5 \mathrm{~h}$ to generate biochar according to Uzoma et al. (2011). After the pyrolysis process, the QLB was ground to pass through a $1.0 \mathrm{~mm}$ sieve so that the biochar had the same particle size as sandy soil used in the experiment. The QLB was alkaline in nature (Suppadit, 2009). The chemical characteristics, nutrients, and heavy metals in the QLB are presented in Table 1.

\section{Location and greenhouse}

The study was conducted under greenhouse conditions and natural light at the Duangkamol Farm in the Dan Khun Thot District, Nakhon Ratchasima Province from September 2010 to January 2011. The environmental temperature during the trial was $22.0-32.0^{\circ} \mathrm{C}$. The trials were performed in a greenhouse that measured $6.0 \mathrm{~m}$ wide $\times 8.0 \mathrm{~m}$ long $\times 2.0 \mathrm{~m}$ high $\left(96.0 \mathrm{~m}^{3}\right)$ under a plastic roof. Corrugated iron and blue netting were used as a border around the greenhouse. The black plastic pots in which the soybeans were planted were $28.0 \mathrm{~cm}$ wide $\times 22.5 \mathrm{~cm}$ high $\left(616 \mathrm{~cm}^{2}\right)$.

\section{Experimental design and data collection}

This study was a completely randomized design with four separate replicates (Gomez and Gomez, 1984). Air-dried soil was prepared for a total weight of $10 \mathrm{~kg} \mathrm{pot}^{-1}$ and mixed with various QLB treatments. The amount of biochar applied in this study was based on previous investigations conducted by Van Zwieten et al. (2010) and Uzoma et al. (2011). The QLB treatments were as follows: T1, control (without QLB); T2, $24.6 \mathrm{~g} \mathrm{pot}^{-1}\left(0.4 \mathrm{~kg} \mathrm{~m}^{-2}\right) ; \mathrm{T} 3,49.2 \mathrm{~g}$ $\operatorname{pot}^{-1}\left(0.8 \mathrm{~kg} \mathrm{~m}^{-2}\right) ; \mathrm{T} 4,73.8 \mathrm{~g} \mathrm{pot}^{-1}\left(1.2 \mathrm{~kg} \mathrm{~m}^{-2}\right) ; \mathrm{T} 5,98.4$ 
$\operatorname{g~pot~}^{-1}\left(1.6 \mathrm{~kg} \mathrm{~m}^{-2}\right)$; and T6, $123 \mathrm{~g} \mathrm{pot}^{-1}\left(2.0 \mathrm{~kg} \mathrm{~m}^{-2}\right)$. The chemical fertilizer (NPK 12-24-12; $10 \mathrm{~g} \mathrm{pot}^{-1}$ ) was applied $20 \mathrm{~d}$ after emergence following suggestions issued by the Chiang Mai Field Crops Research Center (CMFCRC, 2002). The soybean cv. Chiang Mai 60 (CM. 60) was used for evaluation. Soybean seeds were inoculated with Rhizobium spp. for $\mathrm{N}$-fixation and planted in each plastic pot. The soybean seedlings were then thinned 1 wk after emergence leaving four seedlings pot ${ }^{-1}$, and the healthiest plant from each pot was retained. The plants were watered approximately up to the field capacity until the R7 stage (beginning maturity). The entire plot area was weeded by hand. An aqueous solution of tobacco leaves was used for insect control. The following data were recorded: planting date, stage of emergence, number of nodes, height, leaf area, DM, yield (4 plants pot ${ }^{-1} \times$ pods plant ${ }^{-1} \times$ seeds pod $^{-1}$ $\times 1$ seed weight), number of pods per plant, number of seeds per pod and dry weight of 100 seeds.

\section{Chemical analysis}

At the end of the pot experiment, the plant, soybean seed, QLB, and soil samples were sent to the laboratories of Faculty of Industrial Education, King Mongkut's Institute of Technology Ladkrabang and Thailand Institute of Scientific and Technological Research. Seed germination and vigor of harvested seeds were recorded based on ISTA Rules (1985). The soil from each pot was air-dried at $36^{\circ} \mathrm{C}$ until a constant weight was reached, and the soil was then passed through a $4 \mathrm{~mm}$ sieve to separate plant debris. The plants and seeds were oven dried at $70{ }^{\circ} \mathrm{C}$ until a constant weight was reached before weighing to determine DM and chemical analysis. Protein and lipid were measured using the Kjeldahl method with a Kjel-Foss Automatic (Model 16210) and by the Soxhlet extraction method according to the procedures in the Land Development Department (2004) manual. Heavy metals in the plant composition were measured using the atomic-direct aspiration method for $\mathrm{Pb}$ and $\mathrm{Cd}$ and atomic absorption-cold vapor method for $\mathrm{Hg}$ with an atomic absorption spectrophotometer (AAS) according to procedures of Tessier et al. (1979). Heavy metals, macronutrients and micronutrients in the QLB and soil were measured using the inductively coupled plasma atomic emission method with an inductively coupled plasma emission spectrophotometer according to procedures of AOAC $(1970 ; 1980)$. The QLB and soil chemical characteristics in terms of EC and $\mathrm{pH}$ before and after the experiment were determined in a 1:10 ratio (solid:water extracts) using a conductivity meter (electrical conductivity method) and a $\mathrm{pH}$ meter, respectively, according to procedures of Peverill et al. (1999). Cation exchange capacity (CEC) was estimated using an $\mathrm{NH}_{4}{ }^{+}$replacement method according to procedures of Schollenberger and Simon (1945), and the leachates were analyzed for exchangeable cations, including $\mathrm{K}, \mathrm{Ca}$, and $\mathrm{Mg}$, according to procedures of Uzoma et al. (2011).

\section{Data analysis}

Data were analyzed using ANOVA. When significant differences were observed, the Duncan's New Multiple Range Test (DNMRT) of the Statistical Analysis System (SAS version 6.12) was used to test for differences among treatment means at a significance level of $p<0.05$ (SAS Institute, 1996).

\section{RESULTS AND DISCUSSION}

\section{Potential growth and yield}

The differences in the number of soybean nodes and soybean height at the R8 stage (full maturity) were significant for all treatments $(p<0.05)$ (Figure 1). Increasing the content of the QLB corresponded to a slight increase in the number of nodes and plant height, which may have been due to the increase in optimal nutrients for soybean growth. The highest number of nodes per plant (nine nodes) and the tallest plant $(102 \mathrm{~cm})$ were obtained from 98.4 g QLB per pot mixture (T5), and the lowest number of nodes per plant (6.9 nodes) and the shortest plant $(84.0 \mathrm{~cm})$ were obtained from the control group (without QLB; T1).

The differences in the soybean leaf areas were significant for all treatments $(p<0.05)$ (Figure 2). At the reproductive growth stages (Fehr and Caviness, 1977) of R1 (beginning bloom; $632 \mathrm{~cm}^{2} 2$ plants $^{-1}$ ), R3 (beginning pod; $798 \mathrm{~cm}^{2} 2$ plants ${ }^{-1}$ ), R5 (beginning seed; $870 \mathrm{~cm}^{2}$ 2 plants $\left.^{-1}\right)$ and R7 $\left(320 \mathrm{~cm}^{2} 2\right.$ plants $\left.{ }^{-1}\right)$, the highest leaf area values were obtained from the $98.4 \mathrm{~g}$ QLB per pot mixture (T5), and the lowest leaf areas were obtained from the control group (without QLB; T1). These results can be attributed to the effects of the optimal fertilizer level. As the soybean leaf area increased from the R1 stage to R5 stage, the data showed that increasing QLB contents corresponded to increased leaf areas.

The DM production was significantly different for all treatments and all stages of R1, R3, R5, R6 (full seed), $\mathrm{R} 7$, and R8 $(p<0.05)$ (Figure 3). The $98.4 \mathrm{~g}$ QLB per

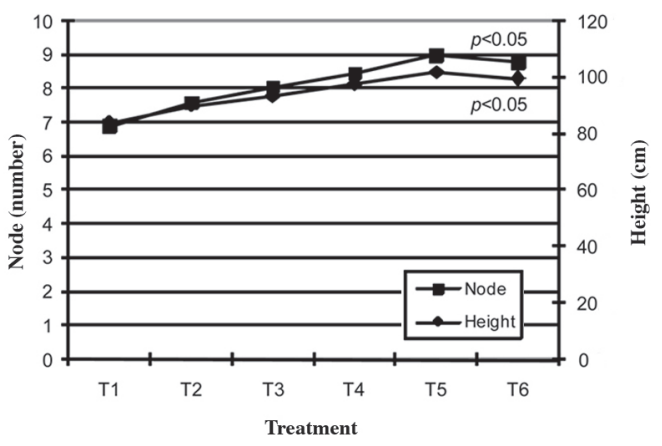

T1: Control (without quail litter biochar); T2: $24.6 \mathrm{~g} \mathrm{pot}^{-1}\left(0.4 \mathrm{~kg} \mathrm{~m}^{-2}\right)$; T3: $49.2 \mathrm{~g} \mathrm{pot}^{-1}$ $\left(0.8 \mathrm{~kg} \mathrm{~m}^{-2}\right)$; T4: $73.8 \mathrm{~g} \mathrm{pot}^{-1}\left(1.2 \mathrm{~kg} \mathrm{~m}^{-2}\right)$; T5: $98.4 \mathrm{~g} \mathrm{pot}^{-1}\left(1.6 \mathrm{~kg} \mathrm{~m}^{-2}\right)$; and T6: $123 \mathrm{~g} \mathrm{pot}^{-1}$ $\left(2.0 \mathrm{~kg} \mathrm{~m}^{-2}\right)$.

Figure 1. Number of main stem nodes and height of soybean cv. CM. 60 at different levels of quail litter biochar. 


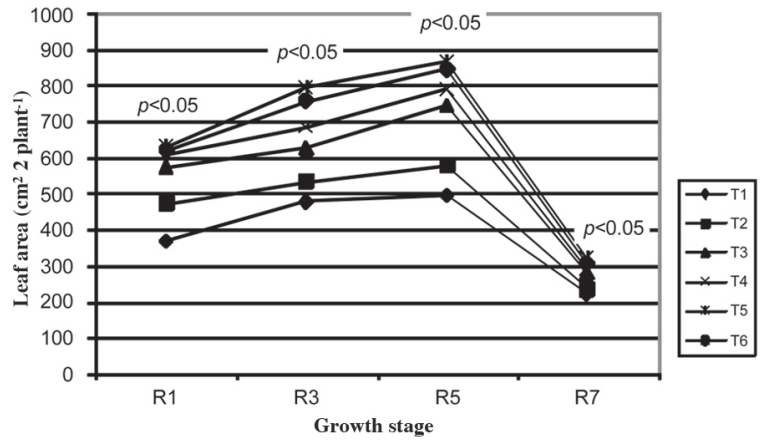

T1: Control (without quail litter biochar); T2: $24.6 \mathrm{~g} \mathrm{pot}^{-1}\left(0.4 \mathrm{~kg} \mathrm{~m}^{-2}\right)$; T3: $49.2 \mathrm{~g} \mathrm{pot}^{-1}$ $\left(0.8 \mathrm{~kg} \mathrm{~m}^{-2}\right)$; T4: $73.8 \mathrm{~g} \mathrm{pot}^{-1}\left(1.2 \mathrm{~kg} \mathrm{~m}^{-2}\right)$; T5: $98.4 \mathrm{~g} \mathrm{pot}^{-1}\left(1.6 \mathrm{~kg} \mathrm{~m}^{-2}\right)$; and T6: $123 \mathrm{~g} \mathrm{pot}^{-1}$ $\left(2.0 \mathrm{~kg} \mathrm{~m}^{-2}\right)$.

Figure 2. Leaf area of soybean cv. CM. 60 at different levels of quail litter biochar.

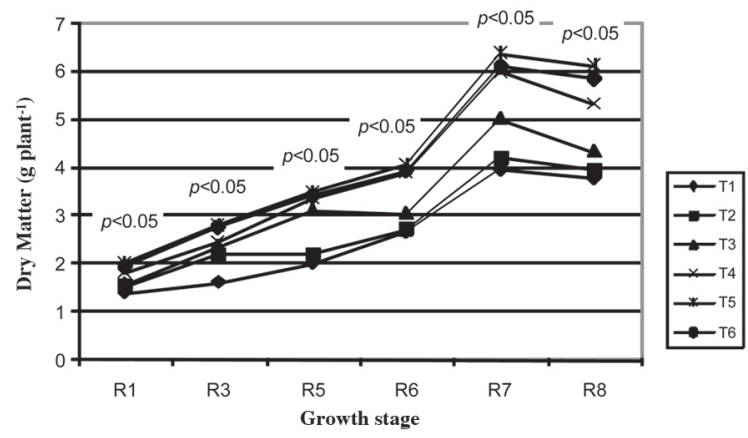

T1: Control (without quail litter biochar); T2: $24.6 \mathrm{~g} \mathrm{pot}^{-1}\left(0.4 \mathrm{~kg} \mathrm{~m}^{-2}\right)$; T3: $49.2 \mathrm{~g} \mathrm{pot}^{-1}$ $\left(0.8 \mathrm{~kg} \mathrm{~m}^{-2}\right)$; T4: $73.8 \mathrm{~g} \mathrm{pot}^{-1}\left(1.2 \mathrm{~kg} \mathrm{~m}^{-2}\right)$; T5: $98.4 \mathrm{~g} \mathrm{pot}^{-1}\left(1.6 \mathrm{~kg} \mathrm{~m}^{-2}\right)$; and T6: $123 \mathrm{~g} \mathrm{pot}^{-1}$ $\left(2.0 \mathrm{~kg} \mathrm{~m}^{-2}\right)$.

Figure 3. Dry matter of soybean cv. CM. 60 at different levels of quail litter biochar.

pot mixture (T5) had the highest DM at stages R7 and R8 with 6.38 and 6.13 g plant $^{-1}$, respectively, and the lowest DM was obtained from the control group (without QLB; T1). The data showed that the DM was increased with increasing QLB contents. The DM accumulation in all treatments had the highest levels at the R7 stage and was slightly decreased at the R8 stage. Similar results were obtained by Hanway and Thomson (1967), who reported that leaf and stem DM accumulates at an early stage (R7) and then decreases at the pod development and seed filling stages. Meanwhile, pod and seed DM accumulates when carbohydrates are moved from sources (leaf and stem) to sinks (pod and seed) at the final stage. Moreover, Hanway and Weber (1971) reported that soybean stem DM accumulation has the highest value approximately 15 $\mathrm{d}$ after the flowering stage and has a lower value at the full maturity stage, and they concluded that carbohydrates are also moved from the stems to the seeds to meet the growth demands for seed development.

The yield ( 4 plants pot $\left.{ }^{-1}\right)$ was significantly different for all treatments $(p<0.05)$ (Table 2$)$ with the highest yield of $22.4 \mathrm{~g} \mathrm{pot}^{-1}$ with the $98.4 \mathrm{~g}$ QLB per pot mixture (T5) and the lowest yield of $6.8 \mathrm{~g} \mathrm{pot}^{-1}$ with the control group (without QLB; T1). The soybean yield was increased with increasing QLB contents. Good plant height and leaf area are important because they are important for photosynthesis, which ultimately affects yield (Uzoma et al., 2011). The CMFCRC (2002) reported that plant yield is influenced by the yield components. The present study showed that the highest yielding treatment (T5) presented high values for the number of pods per plant, number of seeds per pod and 100 seed dry weight.

The number of soybean pods, number of seeds per pod and 100 seeds dry weight were significantly different among treatments $(p<0.05)$ (Table 2). Increasing the content of QLB produced more pods plant ${ }^{-1}$, seeds pod $^{-1}$ and 100 seeds dry weight. The highest values for the number of pods per plant, number of seeds per pod and 100 seeds dry weight were 14.8 pods plant ${ }^{-1}, 2.15$ seeds pod $^{-1}$ and $15.2 \mathrm{~g}$, respectively, for the 98.4 $\mathrm{g}$ QLB per pot mixture (T5), and the control group (without QLB; T1) had the lowest values (6.3 pods plant ${ }^{-1}, 1.8$ seeds pod $^{-1}$, and 10.8 $\mathrm{g}$, respectively).

The above results showed that the application of QLB to sandy soil increased soybean growth and yield compared to the control group (T1). As a soil amendment, the QLB increased the soil fertility. The presence of nutrients in the soil released from the QLB had beneficial and positive influences on soybean growth and yield, including increased nutrient availability, particularly N (Schmidt and Noack, 2000). QLB is not easily degraded by soil microbes, which favor the use of this material in sandy soils (Glaser et al., 2002) because it has a porous material with high surface area (Liang et al., 2006). Thus, QLB can significantly affect the soil moisture and nutrient dynamics (Lehmann et al., 2003; Uzoma et al., 2011). These results imply that the addition of QLB to sandy soil provided percolating soil moisture more residence time within the root zone, thereby making soil moisture and nutrients more available to soybean seedlings growing in the soil and eventually improving crop productivity (Steinbeiss et al., 2009). In addition, the increase in soybean growth and

Table 2. Yield and yield components of soybean cv. CM. 60 at different levels of quail litter biochar.

\begin{tabular}{lcccc}
\hline & & \multicolumn{3}{c}{ Yield component } \\
\cline { 3 - 5 } & & & & 100 \\
Treatment & Yield & Pods plant $^{-1}$ & Seeds pod $^{-1}$ & $\begin{array}{c}\text { seeds dry } \\
\text { weight }\end{array}$ \\
\hline & g pot $^{-1}$ & & & $\mathrm{~g}$ \\
T1 & $6.8 \mathrm{e}$ & $6.3 \mathrm{e}$ & $1.80 \mathrm{e}$ & $10.8 \mathrm{e}$ \\
T2 & $10.4 \mathrm{~d}$ & $8.4 \mathrm{~d}$ & $1.84 \mathrm{~d}$ & $12.3 \mathrm{~d}$ \\
T3 & $15.9 \mathrm{c}$ & $11.6 \mathrm{c}$ & $1.93 \mathrm{c}$ & $12.7 \mathrm{c}$ \\
T4 & $18.6 \mathrm{~b}$ & $13.2 \mathrm{~b}$ & $2.00 \mathrm{~b}$ & $13.9 \mathrm{~b}$ \\
T5 & $22.4 \mathrm{a}$ & $14.8 \mathrm{a}$ & $2.15 \mathrm{a}$ & $15.2 \mathrm{a}$ \\
T6 & $20.5 \mathrm{ab}$ & $14.2 \mathrm{ab}$ & $2.08 \mathrm{ab}$ & $14.6 \mathrm{ab}$ \\
CV $\%$ & 7.78 & 9.10 & 8.35 & 6.17 \\
\hline
\end{tabular}

Means in the same column with different letters are significantly different at $p<0.05$. T1: Control (without quail litter biochar); T2: $24.6 \mathrm{~g} \mathrm{pot}^{-1}\left(0.4 \mathrm{~kg} \mathrm{~m}^{-2}\right)$; T3: $49.2 \mathrm{~g} \mathrm{pot}^{-1}(0.8$ $\left.\mathrm{kg} \mathrm{m}^{-2}\right)$; T4: $73.8 \mathrm{~g} \mathrm{pot}^{-1}\left(1.2 \mathrm{~kg} \mathrm{~m}^{-2}\right)$; T5: $98.4 \mathrm{~g} \mathrm{pot}^{-1}\left(1.6 \mathrm{~kg} \mathrm{~m}^{-2}\right)$; and T6: $123 \mathrm{~g} \mathrm{pot}^{-1}(2.0$ $\left.\mathrm{kg} \mathrm{m}^{-2}\right) ; \mathrm{CV}$ : coefficient of variation. 
yield was mainly due to the improvement in the CEC of the soil and an increase in the nutrient content of the soil (Hossain et al., 2010). However, there was no significant difference in soybean growth and yield between the 98.4 (T5) and 123 (T6) g QLB per pot mixtures $(p>0.05)$. The mixings rate of $123 \mathrm{~g} \mathrm{QLB} \mathrm{pot}^{-1}$ (T6) may not be feasible because the soil had a $\mathrm{pH} 8$ with this treatment. The optimum soil $\mathrm{pH}$ for soybean production is 6.5-7.5 (CMFCRC, 2002; Becerra et al., 2011), and the soil pH was increased with increasing amounts of QLB.

\section{Seed quality}

The effect of QLB treatments on seed germination and vigor was significant $(p<0.05)$ (Table 3$)$. The highest seed germination and vigor values (50.6 and 42.3\%, respectively) were found for the $98.4 \mathrm{~g}$ QLB per pot mixture (T5), and the lowest seed germination and vigor values (34.2 and $30.9 \%$, respectively) were found for the control group (without QLB; T1). Increasing the content of QLB generally increased the percentage of seed germination and vigor. The reasons for this were the same as for soybean growth and yield.

The difference in seed protein levels for all treatments was significant $(p<0.05)$ (Table 3). The $98.4 \mathrm{~g} \mathrm{QLB}$ per pot mixture (T5) showed the highest protein level of $37.9 \%$, and the control group (without QLB; T1) had the lowest protein level of $33.1 \%$. Increasing the content of QLB caused an increase in seed protein or seed $\mathrm{N}$ contents, which suggested that QLB had the ability to release available $\mathrm{N}$ once applied to the soil via mineralization. Van Zwieten et al. (2010) reported that application of

Table 3. Seed quality, protein content and lipid content of soybean cv. CM. 60 at different levels of quail litter biochar.

\begin{tabular}{lcccc}
\hline Treatment & Germination & Vigor & Protein & Lipid \\
\hline & $34.2 \mathrm{e}$ & $30.9 \mathrm{e}$ & $33.1 \mathrm{e}$ & $20.8 \mathrm{a}$ \\
$\mathrm{T} 1$ & $38.6 \mathrm{~d}$ & $34.8 \mathrm{~d}$ & $33.6 \mathrm{~d}$ & $20.6 \mathrm{~b}$ \\
$\mathrm{~T} 2$ & $44.5 \mathrm{c}$ & $38.7 \mathrm{c}$ & $34.5 \mathrm{c}$ & $20.6 \mathrm{~b}$ \\
$\mathrm{~T} 3$ & $48.1 \mathrm{~b}$ & $39.4 \mathrm{~b}$ & $36.0 \mathrm{~b}$ & $19.9 \mathrm{c}$ \\
$\mathrm{T} 4$ & $50.6 \mathrm{a}$ & $42.3 \mathrm{a}$ & $37.9 \mathrm{a}$ & $19.6 \mathrm{~d}$ \\
$\mathrm{~T} 5$ & $49.8 \mathrm{ab}$ & $41.2 \mathrm{ab}$ & $37.2 \mathrm{ab}$ & $19.8 \mathrm{~cd}$ \\
T6 & 6.88 & 7.42 & 6.38 & 5.45 \\
CV $\%$ & & & &
\end{tabular}

Means in the same column with different letters are significantly different at $p<0.05$. T1: Control (without quail litter biochar); T2: $24.6 \mathrm{~g} \mathrm{pot}^{-1}\left(0.4 \mathrm{~kg} \mathrm{~m}^{-2}\right) ; \mathrm{T} 3: 49.2 \mathrm{~g} \mathrm{pot}^{-1}(0.8$ $\left.\mathrm{kg} \mathrm{m}^{-2}\right)$; T4: $73.8 \mathrm{~g} \mathrm{pot}^{-1}\left(1.2 \mathrm{~kg} \mathrm{~m}^{-2}\right)$; T5: $98.4 \mathrm{~g} \mathrm{pot}^{-1}\left(1.6 \mathrm{~kg} \mathrm{~m}^{-2}\right)$; and T6: $123 \mathrm{~g} \mathrm{pot}^{-1}(2.0$ $\left.\mathrm{kg} \mathrm{m}^{-2}\right) ; \mathrm{CV}$ : coefficient of variation. biochar to soil significantly increases uptake of plant $\mathrm{N}$. Increasing plant $\mathrm{N}$ uptake through biochar amendment is one of the ways to improve $\mathrm{N}$ fertilizer use efficiency (Uzoma et al., 2011), especially in sandy soils where $\mathrm{N}$ loss is a major environmental and agronomic problem (Hamer et al., 2004). The difference in seed lipid contents for all treatments was also significant $(p<0.05)$ (Table 3$)$. Increasing the content of QLB corresponded to a decrease in seed lipid content, which is an advantage for soybean milk consumers because lipid content is inversely related to protein content (CMFCRC, 2000). The 98.4 g QLB per pot mixture (T5) had the lowest lipid content of $19.6 \%$, and the control group (without QLB; T1) had the highest lipid content of $20.8 \%$.

\section{Heavy metals}

After the experiment, the levels of $\mathrm{Pb}, \mathrm{Cd}$, and $\mathrm{Hg}$ in the mixed soil differed significantly among treatments $(p<0.05)$ and ranged from $0.450-1.35,0.540-3.78$, and 0.0784-0.0875 mg kg-1, respectively (Table 4). The 123 $\mathrm{g}$ QLB per pot mixture (T6) had the highest $\mathrm{Pb}, \mathrm{Cd}$, and $\mathrm{Hg}$ contents, and the lowest contents for these heavy metals were found in the control group (without QLB; T1). Increasing the content of QLB corresponded to an increase in $\mathrm{Pb}, \mathrm{Cd}$, and $\mathrm{Hg}$ contents. The heavy metal contents decreased continuously after the experiment due to adsorption by the soil, fixation by the soil, microorganism activity, leaching, and soybean absorption (Suppadit et al., 2005; Hossain et al., 2010).

The leaf $\mathrm{Pb}, \mathrm{Cd}$, and $\mathrm{Hg}$ levels were not significantly different among treatments $(p>0.05)$ with ranges of 3.4 to $3.6,3.3$ to 3.5 , and 0.0185 to $0.0197 \mathrm{mg} \mathrm{kg}^{-1}$, respectively (Table 4 ). Increasing the content of QLB did not correspond to an increase of $\mathrm{Pb}, \mathrm{Cd}$, and $\mathrm{Hg}$ accumulation in leaves. Similarly, the $\mathrm{Pb}, \mathrm{Cd}$, and $\mathrm{Hg}$ values in the seeds ranged from 0.940 to $0.956,0.0223$ to 0.0310 , and 0.00200 to $0.00290 \mathrm{mg} \mathrm{kg}^{-1}$, respectively, and these levels were not significantly different among treatments $(p>0.05)$ (Table 4$)$. The accumulation of heavy metals in seeds was lower than in leaves because leaves generally have more time than seeds to absorb the heavy metals (Suppadit et al., 2005).

These results clearly showed that the QLB had higher levels of heavy metals, including $\mathrm{Pb}, \mathrm{Cd}$, and $\mathrm{Hg}$, than

Table 4. Heavy metals in the soil after the experiment, in the soybean leaf (R5), and in the soybean seed (R8).

\begin{tabular}{|c|c|c|c|c|c|c|c|c|c|}
\hline \multirow[b]{2}{*}{ Treatments } & \multicolumn{3}{|c|}{ Soil after experiment } & \multicolumn{3}{|c|}{ Soybean leaf } & \multicolumn{3}{|c|}{ Soybean seed } \\
\hline & $\mathrm{Pb}$ & $\mathrm{Cd}$ & $\mathrm{Hg}$ & $\mathrm{Pb}^{\mathrm{ns}}$ & $\mathrm{Cd}^{\mathrm{ns}}$ & $\mathrm{Hg}^{\mathrm{ns}}$ & $\mathrm{Pb}^{\mathrm{ns}}$ & $\mathrm{Cd}^{\mathrm{ns}}$ & $\mathrm{Hg}^{\text {ns }}$ \\
\hline & & & & & $\mathrm{mg} / \mathrm{kg}$ & & & & \\
\hline $\begin{array}{l}\text { T1 } \\
\text { T2 }\end{array}$ & $0.450 \mathrm{e}$ & $0.540 \mathrm{e}$ & $\begin{array}{l}0.0784 \mathrm{e} \\
0.0822 \mathrm{~d}\end{array}$ & $\begin{array}{l}3.60 \\
3.40\end{array}$ & $\begin{array}{l}3.30 \\
3.30\end{array}$ & $\begin{array}{l}0.0185 \\
0.0186\end{array}$ & $\begin{array}{l}0.940 \\
0.942\end{array}$ & $\begin{array}{l}0.0223 \\
0.0250\end{array}$ & $\begin{array}{l}0.00200 \\
0.00200\end{array}$ \\
\hline $\mathrm{T} 3$ & $0.960 \mathrm{c}$ & $2.10 \mathrm{c}$ & $0.0848 \mathrm{c}$ & 3.40 & 3.35 & 0.0190 & 0.943 & 0.0278 & 0.00240 \\
\hline $\mathrm{T} 4$ & $1.10 \mathrm{~b}$ & $3.15 b$ & $0.0856 \mathrm{~b}$ & 3.50 & 3.40 & 0.0194 & 0.948 & 0.0280 & 0.00270 \\
\hline T5 & $1.28 \mathrm{ab}$ & $3.46 \mathrm{ab}$ & $0.0862 \mathrm{ab}$ & 3.60 & 3.40 & 0.0195 & 0.955 & 0.0289 & 0.00280 \\
\hline T6 & $1.35 \mathrm{a}$ & $3.78 \mathrm{a}$ & $0.0875 \mathrm{a}$ & 3.60 & 3.50 & 0.0197 & 0.956 & 0.0310 & 0.00290 \\
\hline $\mathrm{CV}, \%$ & 10.50 & 9.30 & 8.29 & 4.58 & 5.86 & 2.28 & 11.50 & 9.75 & 7.14 \\
\hline
\end{tabular}

Means in the same column with different letters are significantly different at $p<0.05$.

T1: Control (without quail litter biochar); T2: $24.6 \mathrm{~g} \mathrm{pot}^{-1}\left(0.4 \mathrm{~kg} \mathrm{~m}^{-2}\right)$; T3: $49.2 \mathrm{~g} \mathrm{pot}^{-1}\left(0.8 \mathrm{~kg} \mathrm{~m}^{-2}\right) ; \mathrm{T} 4: 73.8 \mathrm{~g} \mathrm{pot}^{-1}\left(1.2 \mathrm{~kg} \mathrm{~m}^{-2}\right) ; \mathrm{T}^{2}: 98.4 \mathrm{~g} \mathrm{pot}^{-1}\left(1.6 \mathrm{~kg} \mathrm{~m}^{-2}\right) ; \mathrm{and} \mathrm{T}$ : $123 \mathrm{~g} \mathrm{pot}^{-1}(2.0 \mathrm{~kg}$ $\left.\mathrm{m}^{-2}\right)$; CV: coefficient of variation; ns: non significant. 
the sandy soil (Table 1). However, this study detected insignificant bioaccumulation of the heavy metals present in the produced leaves and seeds when using QLB and showed the ability of QLB to immobilize a mixture of heavy metals in soil. Thus, the bioavailable fraction of heavy metals was reduced in the presence of biochar. Hossain et al. (2010) reported that biochar can increase the heavy metal fraction in soils and decrease the uptake of heavy metals. Biochar application reduces the extractability of heavy metals in soil and significantly changes the sequential extractability of metal fractions that contain the available forms of heavy metals in the soil that can be transformed into unexchangeable forms (Qiu and Guo, 2010). Therefore, QLB can significantly affect heavy metal sorption (Uchimiya et al., 2010), act as a barrier against the negative characteristics of heavy metal contamination (Kookana, 2010) and mitigate the adverse influence of heavy metals on growth and yield (Chen et al., 2010).

\section{Chemical characteristics and nutrients}

Table 5 shows the soil chemical characteristics and nutrients after the experiment. QLB increased the chemical characteristics and nutrients of the soil. The EC values were significantly different among treatments $(p$ $<0.05$ ). The $123 \mathrm{~g}$ QLB per pot mixture (T6) showed the highest EC value $\left(0.423 \mathrm{dS} \mathrm{m}^{-1}\right)$, and the lowest EC value $\left(0.110 \mathrm{dS} \mathrm{m}^{-1}\right)$ was found with the control group (without QLB; T1). Soil $\mathrm{pH}$ values were significantly different among treatments $(p<0.05)$ ranging from 6.118.00. All treatments tended to have a higher soil $\mathrm{pH}$ with increasing QLB contents. The differences in the contents of exchangeable cations, including $\mathrm{CEC}, \mathrm{K}, \mathrm{Ca}$, and $\mathrm{Mg}$, and elements, including $\mathrm{C}, \mathrm{N}, \mathrm{C} / \mathrm{N}, \mathrm{P}, \mathrm{K}, \mathrm{Ca}, \mathrm{Mg}, \mathrm{Fe}, \mathrm{Zn}$, $\mathrm{Cu}$, and $\mathrm{Mn}$, were significant for all treatments $(p<0.05)$ with the highest contents obtained for the $123 \mathrm{~g}$ QLB per pot mixture (T6) and the lowest contents obtained for the control group (without QLB; T1).

QLB may have the ability to increase the mineralization of soil organic $\mathrm{N}$ upon its incorporation into soil as a result of the priming effect (Hamer et al., 2004) and increased total C. However, increasing the rate of QLB application increased the soil $\mathrm{C}$ more than the soil $\mathrm{N}$, which was reflected by the significant increase in the $\mathrm{C}: \mathrm{N}$ ratio with increasing QLB rates. The optimal C:N ratio promoted the mineralization of $\mathrm{C}$ compounds by enhancing the growth of microorganisms and releasing the available $\mathrm{N}$ after QLB addition to soil during the pot experiments. In the present study, the levels of exchangeable nutrients $(\mathrm{K}, \mathrm{Ca}$, and $\mathrm{Mg})$ and $\mathrm{CEC}$ in postharvest soil were higher in the treatment where QLB was applied in a greater amount. Exchangeable cations and CEC confirmed that QLB improved the exchangeable cation status and increased the nutrient availability of the soil (Chan et al., 2008). The absorption and retention capacity for nutrient ions released from fertilizer, such as $\mathrm{K}, \mathrm{Ca}$, and $\mathrm{Mg}$, as well as the maintenance of adequate water supply and a slow release of nutrients may have caused this increase in nutrient availability (Eshghi et al., 2010). Lehmann et al. (2003) and Asai et al. (2009) also reported an increase in plant productivity after biochar application, and they attributed this result to the increase in soil available nutrients. Therefore, it can be inferred that higher soybean growth, DM yield, and grain yield is due to the greater availability of nutrients in the soil.

\section{CONCLUSIONS}

QLB provided material for good environmental conditions for the growth and development of soybean plants. Increasing the content of QLB corresponded to an increase in soil fertility, which demonstrated that QLB was an effective soil amendment. The growth and yield of soybeans responded to QLB application. However, a suitable amount of QLB should be used. More than 98.4 $\mathrm{g}$ of QLB per pot mixture should not be used because this amount caused the soil $\mathrm{pH}$ to be above the requirements for soybean. Additional field studies on the long-term effect of QLB on soil physicochemical properties and plant productivity are needed to understand the sustainability of QLB as a soil amendment, including the interaction among QLB, soil, plants and microorganisms.

\section{ACKNOWLEDGEMENTS}

The authors would like to thank the Marshucon Public Company Limited for the muffle furnace. The authors

Table 5. Chemical characteristics and nutrients of the soil after the experiment.

\begin{tabular}{|c|c|c|c|c|c|c|c|c|c|c|c|c|c|c|c|c|c|}
\hline \multirow[b]{2}{*}{ Treatments } & \multirow[b]{2}{*}{$\mathrm{EC}$} & \multirow[b]{2}{*}{$\mathrm{pH}$} & \multicolumn{4}{|c|}{ Exchangeable cations } & \multirow[b]{2}{*}{$\mathrm{C}$} & \multirow[b]{2}{*}{$\mathrm{N}$} & \multirow[b]{2}{*}{$\begin{array}{l}\mathrm{C} / \mathrm{N} \\
\text { ratio }\end{array}$} & \multicolumn{8}{|c|}{ Elements } \\
\hline & & & CEC & $\mathrm{K}$ & $\mathrm{Ca}$ & $\mathrm{Mg}$ & & & & $\mathrm{P}$ & $\mathrm{K}$ & $\mathrm{Ca}$ & $\mathrm{Mg}$ & $\mathrm{Fe}$ & $\mathrm{Zn}$ & $\mathrm{Cu}$ & $\mathrm{Mn}$ \\
\hline & \multicolumn{2}{|l|}{$\mathrm{dS} \mathrm{m}^{-1}$} & 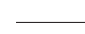 & $\mathrm{cm}$ & $\mathrm{kg}^{-1}$ & - & \multicolumn{2}{|c|}{$-\mathrm{mg} \mathrm{kg}^{-1}$} & & \multicolumn{8}{|c|}{$-\mathrm{mg} \mathrm{kg}^{-1}$} \\
\hline $\mathrm{T} 1$ & $0.110 \mathrm{f}$ & $6.11 f$ & $0.912 \mathrm{f}$ & $0.195 f$ & $0.426 f$ & $0.171 f$ & $1.259 \mathrm{f}$ & $192 \mathrm{f}$ & $6.56 f$ & $576 f$ & $700 f$ & $1.010 \mathrm{f}$ & $312 \mathrm{f}$ & $3.98 \mathrm{f}$ & $0.150 f$ & $0.848 \mathrm{f}$ & 13.1f \\
\hline $\mathrm{T} 2$ & $0.280 \mathrm{e}$ & $6.40 \mathrm{e}$ & $1.24 \mathrm{e}$ & $0.210 \mathrm{e}$ & $0.440 \mathrm{e}$ & $0.211 \mathrm{e}$ & $3.320 \mathrm{e}$ & $200 \mathrm{e}$ & $16.6 \mathrm{e}$ & $620 \mathrm{e}$ & $746 \mathrm{e}$ & $1.045 \mathrm{e}$ & $746 \mathrm{e}$ & $4.22 \mathrm{e}$ & $0.245 \mathrm{e}$ & $0.998 \mathrm{e}$ & $15.8 \mathrm{e}$ \\
\hline $\mathrm{T} 3$ & $0.314 \mathrm{~d}$ & $6.65 \mathrm{~d}$ & $1.39 \mathrm{~d}$ & $0.222 \mathrm{~d}$ & $0.445 \mathrm{~d}$ & $0.225 \mathrm{~d}$ & $3.890 \mathrm{~d}$ & $223 d$ & $17.4 \mathrm{~d}$ & $636 \mathrm{~d}$ & $763 d$ & $1.052 \mathrm{~d}$ & $763 d$ & $4.65 \mathrm{~d}$ & $0.352 d$ & $1.10 \mathrm{~d}$ & $18.4 \mathrm{~d}$ \\
\hline $\mathrm{T} 4$ & $0.326 \mathrm{c}$ & $6.92 \mathrm{c}$ & $1.45 \mathrm{c}$ & $0.232 \mathrm{c}$ & $0.453 c$ & $0.238 \mathrm{c}$ & $4.548 \mathrm{c}$ & $229 \mathrm{c}$ & $19.9 \mathrm{c}$ & $643 c$ & $785 c$ & $1.063 \mathrm{c}$ & $785 c$ & $5.24 \mathrm{c}$ & $0.456 \mathrm{c}$ & $1.25 \mathrm{c}$ & $20.0 \mathrm{c}$ \\
\hline T5 & $0.352 b$ & $7.35 b$ & $1.50 \mathrm{~b}$ & $0.238 \mathrm{~b}$ & $0.464 \mathrm{~b}$ & $0.247 \mathrm{~b}$ & $5.214 b$ & $238 b$ & $21.9 \mathrm{~b}$ & $654 \mathrm{~b}$ & $802 \mathrm{~b}$ & $1.070 \mathrm{~b}$ & $802 b$ & $5.55 \mathrm{~b}$ & $0.558 b$ & $1.40 \mathrm{~b}$ & $22.5 b$ \\
\hline T6 & $0.423 \mathrm{a}$ & $8.00 \mathrm{a}$ & $1.58 \mathrm{a}$ & $0.246 \mathrm{a}$ & $0.478 \mathrm{a}$ & $0.259 \mathrm{a}$ & $6.325 \mathrm{a}$ & $245 a$ & $25.8 \mathrm{a}$ & $668 a$ & $812 a$ & $1.078 \mathrm{a}$ & $812 a$ & $5.98 \mathrm{a}$ & $0.698 \mathrm{a}$ & $1.68 \mathrm{a}$ & $24.8 \mathrm{a}$ \\
\hline $\mathrm{CV}, \%$ & 10.6 & 5.83 & 10.5 & 8.86 & 5.92 & 6.63 & 9.70 & 8.42 & 9.10 & 5.43 & 6.24 & 4.40 & 6.24 & 12.3 & 14.8 & 7.48 & 4.95 \\
\hline
\end{tabular}
Means in the same column with different letters are significantly different at $p<0.05$.
T1: Control (without quail litter biochar); T2: $24.6 \mathrm{~g} \mathrm{pot}^{-1}\left(0.4 \mathrm{~kg} \mathrm{~m}^{-2}\right) ; \mathrm{T} 3: 49.2 \mathrm{~g} \mathrm{pot}^{-1}\left(0.8 \mathrm{~kg} \mathrm{~m}^{-2}\right) ; \mathrm{T} 4: 73.8 \mathrm{~g} \mathrm{pot}^{-1}\left(1.2 \mathrm{~kg} \mathrm{~m}^{-2}\right) ; \mathrm{T}^{2}: 98.4 \mathrm{~g} \mathrm{pot}^{-1}\left(1.6 \mathrm{~kg} \mathrm{~m}^{-2}\right) ;$ and T6: $^{2} 23 \mathrm{~g} \mathrm{pot}^{-1}(2.0 \mathrm{~kg}$ $\left.\mathrm{m}^{-2}\right) ; \mathrm{CV}$ : coefficient of variation. 
would also like to thank the Faculty of Industrial Education, King Mongkut's Institute of Technology Ladkrabang, Thailand Institute of Scientific and Technological Research and Duangkamol Farm for laboratory and material support.

\section{Efecto del uso de biocarbón de lecho de codorniz en} la producción de soya (Glycine max [L.] Merr.). El biocarbón puede usarse como enmienda para mejorar las propiedades del suelo y el rendimiento del cultivo. El objetivo de esta investigación fue el estudio del crecimiento de la planta, rendimiento y sus características, así como la calidad de semilla, incluyéndose el estudio de nutrientes y metales pesados $(\mathrm{Pb}, \mathrm{Cd}$ y $\mathrm{Hg}$ ) en la planta de soya (Glycine $\max$ [L.] Merr.) y el suelo. La experimentación se realizó en condiciones de invernadero en el distrito de Dan Khun Thot, provincia de Nakhon Ratchasima, Tailandia, entre septiembre del 2010 y enero del 2011. La investigación constó de seis tratamientos con cuatro repeticiones en un diseño completamente al azar. Se administró biocarbón de lecho de codorniz (QLB) a razón de 0, 24,6; 49,2; 73,$8 ; 98,4$ y 123 g por mezcla de sustrato en maceta, a soya var. Chiang Mai 60 . Los resultados mostraron que el QLB puede usarse para mejorar la fertilidad y como enmienda del suelo en la producción de soja a un nivel óptimo de $98.4 \mathrm{~g}$ por mezcla de sustrato en maceta. Esta medida dio el mejor resultado en número de nodos, altura, acumulación de materia seca, rendimiento total, y calidad de semilla. El contenido de nutrientes en suelo tras el experimento aumentó al aumentar QLB, mientras que el residuo de metales pesados en hoja y semilla no cambió. No obstante, no se recomiendan niveles superiores a 98.4 $\mathrm{g}$ de QLB por mezcla de sustrato en maceta dado que el QLB es de naturaleza alcalina y el $\mathrm{pH}$ del suelo podría verse afectado.

Palabras clave: rendimiento de cultivo, elementos, absorción de nutrientes, pirólisis, fertilidad del suelo.

\section{LITERATURE CITED}

AOAC. 1970. Official methods of analysis. 1015 p. $11^{\text {th }}$ ed. Association of Official Analytical Chemists (AOAC), Washington, D.C., USA.

AOAC. 1980. Official methods of analysis. 1018 p. $13^{\text {th }}$ ed. Association of Official Analytical Chemists (AOAC), Washington, D.C., USA.

Asai, H., B.K. Samson, H.M. Stephan, K. Songyikhangsuthor, K. Homma, Y. Kiyono, et al. 2009. Biochar amendment techniques for upland rice production in Northern Laos. 1. Soil physical properties, leaf SPAD and grain yield. Field Crop Research 111:81-84.

Becerra, V., M. Paredes, and D. Debouck. 2011. Genetic relationships of common bean (Phaseolus vulgaris L.) race Chile with wild Andean and Mesoamerican germplasm. Chilean Journal of Agricultural Research 71:3-15.

Bernhart, M., and O.O. Fasina. 2008. Moisture effect on the storage, handling and flow properties of poultry litter. Waste Management 29:1392-1398.
Chan, K.Y., L. Van Zwieten, I. Meszaros, A. Downie, and S. Joseph. 2008. Using poultry litter biochars as soil amendments. Soil Research 46:437-444.

Chen, Y., Y. Shinogi, and M. Taira. 2010. Influence of biochar use on sugarcane growth, soil parameters, and groundwater quality. Soil Research 48:526-530.

CMFCRC. 2000. Varieties of soybean in Thailand. 20 p. Somporn Printing Press, Chiang Mai Field Crops Research Center (CMFCRC), Department of Agriculture, Ministry of Agriculture and Cooperatives, Chiang Mai, Thailand.

CMFCRC. 2002. Physiology of soybean growth, development and management. 36 p. Chiang Mai Field Crops Research Center (CMFCRC), Department of Agriculture, Ministry of Agriculture and Cooperatives, Chiang Mai, Thailand.

Department of Livestock Development. 2010. Quail production in Thailand. 21 p. Ministry of Agriculture and Cooperatives, Bangkok, Thailand.

Eshghi, S., M.R. Mahmoodabadi, G.R. Abdi, and B. Jamali. 2010. Zeolite ameliorates the adverse effect of cadmium contamination on growth and nodulation of soybean plant (Glycine $\max \mathrm{L}$.) Journal of Biology \& Environmental Science 4:43-50.

Fehr, W.R., and C.E. Caviness. 1977. Stages of soybean development. Special Report 80. 12 p. Iowa State University, Iowa, USA.

Glaser, B., J. Lehmann, and W. Zech. 2002. Ameliorating physical and chemical properties of highly weathered soils in the tropics with charcoal - a review. Biology and Fertility of Soils 35:219-230.

Gomez, K.A., and A.A. Gomez. 1984. Statistical procedures for agricultural research. 704 p. $2^{\text {nd }}$ ed. John Wiley \& Sons, New York, USA.

Gupta, G., and W. Gardner. 2005. Use of clay mineral (Montmorillonite) for reducing poultry litter leachate toxicity $\left(\mathrm{EC}_{50}\right)$. Journal of Hazardous Materials 118:81-83.

Hamer, U., B. Marschner, S. Brodowski, and W. Amelung. 2004. Interactive priming of black carbon and glucose mineralization. Organic Geochemistry 35:823-830.

Hanway, J.J., and H.E. Thomson. 1967. How a soybean plant develops. Special Report 53. 18 p. Iowa State University Cooperative Extension Service, Ames, Iowa, USA.

Hanway, J.J., and C.R. Weber. 1971. N, P, and K percentages in soybean (Glycine max (L.) Merrill) plant parts. Agronomy Journal 63:286-290.

Hossain, M.K., V. Strezov, K. Yin Chan, and P.F. Nelson. 2010. Agronomic properties of wastewater sludge biochar and bioavailability of metals in production of cherry tomato (Lycopersicon esculentum). Chemosphere 78:1167-1171

ISTA Rules. 1985. International rules for seed testing. Seed Science and Technology 13:299-355.

Iwamoto, S., S. Sato, K. Hosomichi, A. Taweetungtragoon, T. Shiina, H. Matsubayashi, et al. 2008. Identification of heat shock protein 70 genes HSPA2, HSPA5 and HSPA8 from the Japanese quail, Coturnix japonica. Animal Science Journal 79:171-181.

Jaime, M.M., and C.A. Salazar. 2010. Participation in organizations, technical efficiency and territorial differences: A study of small wheat farmers in Chile. Chilean Journal of Agricultural Research 71:104-113

Kookana, R.S. 2010. The role of biochar in modifying the environmental fate, bioavailability, and efficacy of pesticides in soils: a review. Soil Research 48:627-637.

Land Development Department. 2004. Plant, fertilizer, water and soil analysis manual. 184 p. Ministry of Agriculture and Cooperatives, Bangkok, Thailand.

Land Development Department. 2011. Dan Khun Thot series: DK. 3 p. Ministry of Agriculture and Cooperatives, Bangkok, Thailand.

Lehmann, J. 2007. Carbon sequestration in dryland ecosystems. Environmental Management 33:528-544.

Lehmann, J., J.P. Da Silva, C. Steiner, T. Nehls, W. Zech, and B. Glaser. 2003. Nutrient availability and leaching in an archaeological Anthrosol and a Ferralsol of the Central Amazon basin: fertilizer, manure and charcoal amendments. Plant and Soil 249:343-357. 
Lehmann, J., J. Gaunt, and M. Rondon. 2006. Biochar sequestration in terrestrial ecosystems a review. Mitigation and Adaptation Strategies for Global Change 11:403-427.

Liang, B., J. Lehmann, and D. Solomon. 2006. Black carbon increases cation exchange capacity in soils. Soil Science Society of American Journal 70:1719-1730.

Lopez-Mosquera, M.E., F. Cabaleiro, M.J. Sainz, A. Lopez-Fabal, and E. Carral. 2007. Fertilizing value of broiler litter: effect of drying and pelleting. Bioresource Technology 99:5626-5633.

Peverill, K.I., L.A. Sparrow, and D.J. Reuter. 1999. Soil analysis and interpretation manual. 369 p. CSIRO Publishing, Melbourne, Australia.

Qiu, G., and M. Guo. 2010. Quality of poultry litter-derived granular activated carbon. Bioresource Technology 101:379-386.

SAS Institute. 1996. SAS user's guide: statistics. 956 p. $4^{\text {th }}$ ed. SAS Institute, Cary, North Carolina, USA.

Schmidt, M.W.I., and A.G. Noack. 2000. Black carbon in soils and sediments: analysis, distribution, implications, and current challenges. Global Biogeochemical Cycles 14:777-793.

Schollenberger, C.J., and R.H. Simon. 1945. Determination of exchange capacity and exchangeable bases in soil-ammonium acetate method. Soil Science 59:13-24.

Steinbeiss, S., G. Gleixner, and M. Antonietti. 2009. Effect of biochar amendment on soil carbon balance and soil microbial activity. Soil Biology \& Biochemistry 41:1301-1310.

Suppadit, T. 2002. The recycle of broiler litter as a feed ingredient for cattle to reduce environmental pollution I. Impact of broiler litter on environmental states and community health. Thai Environmental Consultant Journal 6:12-17.

Suppadit, T. 2005. The recycle of broiler litter as a feed ingredient for cattle to reduce environmental pollution V. Production performance of fattening cattle. Thai Environmental Consultant Journal 9:44-48.
Suppadit, T. 2009. Pollution from animal excreta on environmental health. 818 p. $3^{\text {rd }}$ ed. Tippanate Printing Press, Bangkok, Thailand.

Suppadit, T., S. Jaturasitha, W. Selasat, R. Norkeaw, P. Poungsuk, and N. Pripwai. 2009. Effect of dietary dried milky sludge on productive performance and egg quality in laying Japanese quails. Animal Science Journal 80:310-315.

Suppadit, T., L. Sangla, and A. Chaiyo. 2008a. Utilization of pelleted broiler litter as a substitute for chemical fertilizer in soybean (Glycine max) production. Indian Journal of Agricultural Science 78:59-64.

Suppadit, T., L. Sangla, S. Kunnoot, and K. Sermviriyakul. 2005. Sewage sludge as fertilizer in soybean production. Journal of International Society for Southeast Asian Agricultural Sciences 11:75-83.

Suppadit, T., L. Sangla, and L. Udompon. 2008b. Layer chicken parent stock pelleted litter as fertilizer in soybean production. Philippine Journal of Science 137:53-60.

Tessier, A., P.G.C. Campbell, and M. Bisson. 1979. Sequential extraction procedure for the speciation of particulate trace metals. Analytical Chemistry 51:844-851.

Uchimiya, M., I.M. Lima, K.T. Klasson, S. Chang, L.H. Wartelle, and J. Rodgers. 2010. Immobilization of heavy metal ions $\left(\mathrm{Cu}^{\mathrm{II}}\right.$, $\mathrm{Cd}^{\mathrm{II}}, \mathrm{Ni}^{\mathrm{II}}$, and $\left.\mathrm{Pb}^{\mathrm{II}}\right)$ by broiler litter-derived biochars in water and soil. Journal of Agriculture and Food Chemistry 58:5538-5544.

Uzoma, K.C., M. Inoue, H. Andry, H. Fujimaki, A. Zahoor, and E. Nishihara. 2011. Effect of cow manure biochar on maize productivity under sandy soil condition. Soil Use Management doi:10.1111/j.1475-2743.2011.00340.x.

Van Zwieten, L., S. Kimber, S. Morris, K.Y. Chan, A. Downie, J. Rust, et al. 2010. Effect of biochar from slow pyrolysis of papermill waste on agronomic performance and soil fertility. Plant and Soil 327:235-246. 